\title{
Challenges Facing the Multi-Stakeholder Partnerships in Implementing SDG's Goal: Poverty Reduction in Indonesia
}

\author{
Roy Andy Panjaitan, SE, MBA \\ Pelita Harapan University
}

\begin{abstract}
Despite having a significant achievement in reducing the extreme poverty level before the year of 2015, there are many things yet to be done in Indonesia to reach the number one goal of SDGs, ending poverty in all of its manifestations, including extreme poverty by 2030. Due to the comprehensive nature and ambitious goals of the SDGs, strong commitment from all relevant stakeholders to cooperate in multi-stakeholder partnerships setting in achieving the goals is indeed very crucial. The multi-stakeholder partnership approach is needed in reducing poverty matters since each stakeholder will bring each of their core competence, unique knowledge, and skills, assets and resources, as well as a wealth of experiences in dealing with poverty issues. As a result, there will be synergies developed to co-create innovative solutions to tackle poverty issues more efficiently that none of the stakeholders could have developed on their own. Multiple in-depth interviews held with each respective stakeholder involved in the SDGs poverty reduction initiative. Nevertheless, there are still several challenges facing the partnership that is needed to be solved, such as coordination difficulties among several stakeholders, compartmentalized or 'silo' approaches in addressing poverty issues, different perceptions in understanding the goals, and other communication issues. Therefore, several solutions recommended to solve these problems are: intensifying the communication efforts with all respective stakeholders to build consensus, trust, and mutual understanding; engaging more stakeholders; and looking for more innovative approaches in ensuring development financing participation coming from the private sector.
\end{abstract}

Key Words -Poverty, Post-2015, SDGs, Stakeholders, Partnership

\section{I.1. Background}

\section{PREFACE}

Eradicating poverty is the greatest global challenge facing the world today and an indispensable requirement for sustainable development.

(Transforming Our World: The 2030 Agenda for Sustainable Development, United Nations)

Since the beginning of the millennium, the world has been continually facing the most pressing and unprecedented challenges to humanity such as extreme poverty and hunger, child and maternal mortality, inequalities within and among countries, as well as the threat of climate change crisis[1]. To tackle these urgent and significant issues, the leaders of the nations have made a historic agreement at the United Nations Conference on Sustainable Development in Rio de Janeiro in 2012 (Rio+20). It intends to continue the unfinished tasks of development priorities which have been started since the implementation of the Millenium Development Goals (MDGs) in the year 2000. One of the most important outcomes of the Rio+20 summit was the establishment of a new set of universal development goals called the Sustainable Development Goals (SDGs), which replaced the MDGs that was officially expired in 2015[2].

The basic understanding of the meaning of Sustainable Development itself came initially from the work of the Brundtland Commission established by the United Nations in October 1987, commonly known as "The Brundtland Report." Sustainable Development is defined as "development that meets the needs of the present without compromising the ability of future generations to meet their own needs"[3]. This term was coined by the Commission to instill the new understanding to the world at that time on the necessity of keeping the safe environment while at the same time making good progress towards the economic development achievements.

The primary purpose of the SDGs itself was to complete on what the MDGs did not achieve yet. It was explicitly done in addressing the urgent need of having a set of development goals and targets which is people-centered, comprehensive and encompassing all related dimensions - economic, social, and environmental - in an integrated and interdependent manner[4]. The journey, as well as the process of setting up the goals, was unique compared to MDGs. MDGs was considered to be heavily depended on the initiatives from the UN bodies and agencies in establishing its directions. SDGs, on the other hand, has been designed to utilize a bottom-up approach regarding involving all respective stakeholders during the two years of 
intensive public consultations. It was held before launching the document, in particular by incorporating the voices of the poorest and most vulnerable into the discussion, which sadly too often has been left out from many similar international development forums[5].

Digging deeper into the goals and targets of SDGs itself, there are 17 (seventeen) goals that have been established and endorsed by the General Assembly of the UN following the inclusive and intensive process of several intergovernmental negotiations[4] (see Appendix 1 for the list of the goals). Although these goals were primarily set on a global scale of ambition and aspiration, nevertheless, it also considered different capacities, realities, and complexities of each countries' level of development. Therefore, each government has to set its domestic targets and goals based on their national circumstances and incorporate each of the global objectives into their ongoing and long-term national policies, programs, and strategies.

As such, this paper will thoroughly examine the profile of each stakeholder involved in implementing the poverty reduction programs to achieve the number one goal of SDGs. Besides, it also intends to explore how they contribute to reducing poverty in Indonesia, what are the challenges facing the multi-stakeholder partnership cooperation in Indonesia, and what would be the solutions recommended to overcome those obstacles.

\section{I.2. Research Questions}

1. How do the multi-stakeholder partnerships contribute to the SDGs Goal No 1 in reducing poverty in Indonesia?

2. What are the challenges in implementing multistakeholder partnerships to achieve SDGs Goal No 1 in Indonesia?

3. What are the solutions recommended for those challenges?

\section{I.3. Purpose \& Objectives}

The purpose and objectives of this research study are:

1. To discuss the contributions and engagement of each partner in the multi-stakeholder partnerships in reducing poverty in Indonesia.

2. To elaborate the challenges facing the multistakeholder partnerships in implementing programs to achieve SDGs Goal number one in Indonesia.

3. To provide recommendations for solving the challenges facing the multi-stakeholder partnerships.

\section{I.4. Research Methodology.}

This qualitative research combines both primary and secondary data collection methods. The primary data collection was accomplished through the in-depth interviews with selected representatives from each respective stakeholders involved with the poverty reduction programs and SDGs initiatives in Indonesia. Meanwhile, the second method implemented was analyzing previous research reports, journals and international publications related to the topic of the paper.

\section{I.5. Expected Outcome}

The outcome of this study is expected to be utilized as a valuable input for the policy-making activities of the national government. It also aims to be a significant research for the academia in understanding the dynamics of the multistakeholder partnerships thoroughly, as well as assisting the civil society and international donors in enhancing their collaboration work with the government and private sector in general.

\section{HOW DO THE MULTI-STAKEHOLDER PARTNERSHIP CONTRIBUTE TO REDUCING POVERTY?}

Recently, the President of the Republic of Indonesia has just signed his new Presidential Decree (Peraturan Presiden) Number 59 in July 2017 as an official regulation as well as the regulatory umbrella for the government to start implementing development programs to achieve the goals of the SDGs in the country. In this decree, the President officially announced the formal organizational structure which consisted of multiple stakeholders with respective responsibilities to work together so that the goals of the SDGs can be met in accordance to the national purposes stated in the National Medium Term Development Plan 2015-2019 (RPJMN 20152019). President Jokowi has formed one National Coordination Team which consisted of the Steering Committee, the Implementation Team, the Working Groups, and the Expert Team (see Appendix 2 for the organizational structure). Under this new structure, the Government of Indonesia (GOI) has officially acknowledged the involvement and participation of other stakeholders outside of the government bodies to contribute to the achievement of the SDGs goals in 2030.

Each of the stakeholders in the National Coordination Team has a significant part in contributing to the achievement of reducing poverty from their respective capabilities and resources, as has been discussed in the previous segment of this paper. For example, for the GOI, in particular, Bappenas, as has been mentioned by Dr. Vivi Yulaswati, MSc from the Directorate of 
Poverty Reduction of Bappenas during the in-depth interview process, the first capabilities and expertise of the government is the planning and setting capacity of the national poverty reduction targets and the poverty reduction indicators. Besides, it is also coordinating the implementation of the national programs and setting up the national poverty reduction budgets that will be implemented by the other respective government agencies in Indonesia. Also, the Directorate of Poverty Reduction of Bappenas is capable of offering training and policy analysis to the different sectors in the government bodies to have a better comprehension of poverty issues. In this regards, the role of other development partners, in particular, the international development organizations such as DFAT, the UN Agencies, the World Bank, the Asian Development Bank, JICA, and other international partners is very crucial. It is said so because they are essential in providing their capabilities to government agencies in the form of policy advice and technical analysis on poverty measurement indicators, capacity building programs for the government workers, and bringing best practices of other countries poverty reduction projects. It is a benchmark for the GOI to learn from and to implement in Indonesia, as has been confirmed by Dr. Arum Atmawikarta from the Executive Secretariat of SDGs during the in-depth interview process.

As Indonesia is already becoming part of the middle-income countries as well as a member of the G20 nations, many multilateral development organizations are no longer providing the nation with much funding assistance per se. Therefore, the GOI has started to look from other sources of financial aid to fund the national poverty reduction programs, including from the philanthropy and private sector. As what has been mentioned during the in-depth interview process with the representative from the Indonesian Philanthropy Association (Timotheus Lesmana Wanadjaja), the resources and capabilities that have been offered by the business and philanthropy communities to contribute to the achievements of the number one goal of SDGs are mainly in the form of mobilizing financial resources to support the government's limited funding capacity. Also, they are providing capacity building to the government agencies through the recommendation of innovative approach and latest technologies in reducing poverty, as well as sharing best practices from corporate social responsibilities (CSR) programs held by many corporations in the field. In addition, as what has been mentioned by the Special Assistant to the United Nations Representative in Indonesia during the interview process, Mr. Erlend Arneson Haugen, the philanthropy, and business community is capable of contributing to the achievements of the poverty reduction goals of SDGs by implementing responsible business practices, pro-poor, and pro-environment programs in each of their respective sectors.

In regards to the academia, universities and experts community, the capabilities and resources that are expected from their participation in the national coordination team are mainly by providing sound policy recommendation to the government on innovative approach in poverty reduction efforts. It can be done through academic research writings as well as policy brief, providing evaluating and monitoring assistance in the implementation process of the poverty reduction programs[6]. Furthermore, they can educate the poor community themselves on how to leave their poverty state through direct involvement in voluntary community services, as what has been mentioned by Sylvia Yazid, Ph.D. from Parahyangan University during the interview process.

When it comes to the capabilities of the civil society organizations, their unique contributions to the achievements of the SDGs goals in reducing poverty are mainly through ensuring that the voice and needs of the poor and marginalized community are heard and counted throughout all of the policymaking processes in the government offices. They also can facilitate and engage the poor communities in the field directly, advocate the local community organizations as well as local government officials on the importance of the SDGs goals, and monitor the implementation process of the poverty reduction programs accordingly, as has been stated by Hamong Santono from INFID during the indepth interview process.

\section{WHAT ARE THE CHALLENGES FACING THE MULTI-STAKEHOLDER PARTNERSHIP?}

According to the multiple in-depth interviews held with each respective stakeholders involved in the SDGs poverty reduction initiatives, there are still several challenges facing the multistakeholders partnership approach that is needed to be solved. Those main problems are as follows:

1. The coordination difficulties among several stakeholders since many of the stakeholders are already having their poverty reduction programs as well as the SDGs related initiatives (this is mainly due to the 'classic' sectoral ego issues). It also has caused many overlapping programs and budgets in the government agencies, compartmentalized or 'silo' approach to solving poverty issues.

2. Different perception among stakeholders in understanding the goals and targets of the national poverty reduction as well as the SDGs goals, 
3. Trust-building and mutual respect as well as communication issues (for instances, between the civil society organizations and private sector, between the private sector and the government), and

4. The most important is how to ensure that the national SDGs goals and poverty reduction targets can be understood, adopted, and contextualized by the regional and local government in all provinces in Indonesia. It is since not all national poverty reduction programs, and goals are implemented in the local areas of the country due to the different domestic poverty issues. It is the regional and local government officials that hold the key to the success of the national government in achieving the SDGs goals in reducing poverty.

\section{RECOMMENDED SOLUTIONS TO THE CHALLENGES FACING THE MULTI-STAKEHOLDER PARTNERSHIP}

Several recommendations are worthy to be highlighted to solve the challenges facing the multi-stakeholder partnerships as what has been revealed from several in-depth interviews process with various stakeholders. Those suggestions are as follows:

1. Enhancing and intensifying the communication efforts with all respective stakeholders to build consensus, trust, and mutual understanding so that the coordination process in implementing the programs can be done more smoothly and efficiently. It can be done by holding routine meetings among the National Coordination Team members, engaging more stakeholders that have not been involved yet in the discussion process of SDGs goals while their contributions are very crucial to achieve the goals (e.g., the private sector, academia, media partners, local civil society organizations in particular faith-based organizations, and most importantly the regional and local government officials).

2. Another recommendation coming from the international donors is that their role should be acknowledged in the multi-stakeholder partnership and when possible at all, the donors should also be included in the government's platform of the SDG's National Implementation Team, in addition to the other 4 (four) respective stakeholders.

3. Last excellent recommendation from Alexander Irwan, Senior Program Officer from Ford Foundation during the interview process was that the GOI should look for more innovative approaches in ensuring development financing participation from the private sector, such as increasing the tax revenues from large corporations and inviting more private sector investment, in order to support the government-owned existing and future poverty reduction programs in the country. 


\section{References}

[1] J. D. Sachs, "From millennium development goals to sustainable development goals," Lancet, vol. 379, no. 9832, pp. 2206-2211, 2012.

[2] Sustainable Development Knowledge Platform of the United Nations, "The Future We Want: Outcome Document of the United Nations Conference on Sustainable Development Rio+20," Rio de Janeiro, 2012.

[3] United Nations Commission on Sustainable Development, "Framing Sustainable Development
The Brundtland Report - 20 Years On,” p. 2, 2007.

[4] UNGA, "Transforming Our World: The 2030 Agenda for Sustainable Development (UNGA Resolution A/RES/70/1, 25 September 2015) ('2030 Agenda').," 2015.

[5] United Nations, "An Action Agenda for Sustainable Development: Report for the UN Secretary-General," 2014.

[6] W. Darajati, "UPAYA PENCAPAIAN TARGET TUJUAN PEMBANGUNAN BERKELANJUTAN ( TPB),’Bappenas, DKI Jakarta, 2016. 


\begin{tabular}{|c|c|}
\hline $\begin{array}{l}\text { Goal } \\
1\end{array}$ & End poverty in all its forms everywhere \\
\hline $\begin{array}{l}\text { Goal } \\
2\end{array}$ & $\begin{array}{l}\text { End hunger, achieve food security and improved nutrition and promote sustainable } \\
\text { agriculture }\end{array}$ \\
\hline $\begin{array}{l}\text { Goal } \\
3\end{array}$ & Ensure healthy lives and promote well-being for all at all ages \\
\hline $\begin{array}{l}\text { Goal } \\
4\end{array}$ & $\begin{array}{l}\text { Ensure inclusive and equitable quality education and promote lifelong learning } \\
\text { opportunities for all }\end{array}$ \\
\hline $\begin{array}{l}\text { Goal } \\
5\end{array}$ & Achieve gender equality and empower all women and girls \\
\hline $\begin{array}{l}\text { Goal } \\
6\end{array}$ & Ensure availability and sustainable management of water and sanitation for all \\
\hline $\begin{array}{l}\text { Goal } \\
7\end{array}$ & Ensure access to affordable, reliable, sustainable and modern energy for all \\
\hline $\begin{array}{l}\text { Goal } \\
8\end{array}$ & $\begin{array}{l}\text { Promote sustained, inclusive and sustainable economic growth, full and productive } \\
\text { employment and decent work for all }\end{array}$ \\
\hline $\begin{array}{l}\text { Goal } \\
9\end{array}$ & $\begin{array}{l}\text { Build resilient infrastructure, promote inclusive and sustainable industrialization and foster } \\
\text { innovation }\end{array}$ \\
\hline $\begin{array}{l}\text { Goal } \\
10\end{array}$ & Reduce inequality within and among countries \\
\hline $\begin{array}{l}\text { Goal } \\
11\end{array}$ & Make cities and human settlements inclusive, safe, resilient and sustainable \\
\hline $\begin{array}{l}\text { Goal } \\
12\end{array}$ & Ensure sustainable consumption and production patterns \\
\hline $\begin{array}{l}\text { Goal } \\
13\end{array}$ & Take urgent action to combat climate change and its impacts* \\
\hline $\begin{array}{l}\text { Goal } \\
14\end{array}$ & $\begin{array}{l}\text { Conserve and sustainably use the oceans, seas and marine resources for sustainable } \\
\text { development }\end{array}$ \\
\hline $\begin{array}{l}\text { Goal } \\
15\end{array}$ & $\begin{array}{l}\text { Protect, restore and promote sustainable use of terrestrial ecosystems, sustainably } \\
\text { manage forests, combat desertification, and halt and reverse land degradation and halt } \\
\text { biodiversity loss }\end{array}$ \\
\hline $\begin{array}{l}\text { Goal } \\
16\end{array}$ & $\begin{array}{l}\text { Promote peaceful and inclusive societies for sustainable development, provide access to } \\
\text { justice for all and build effective, accountable and inclusive institutions at all levels }\end{array}$ \\
\hline $\begin{array}{l}\text { Goal } \\
17\end{array}$ & $\begin{array}{l}\text { Strengthen the means of implementation and revitalize the global partnership for } \\
\text { sustainable development }\end{array}$ \\
\hline
\end{tabular}




\section{APPENDIX 2- ORGANIZATION STRUCTURE OF NATIONAL COORDINATION TEAM OF SDGs in INDONESIA (Presidential Decree No. 59 in 2017).}

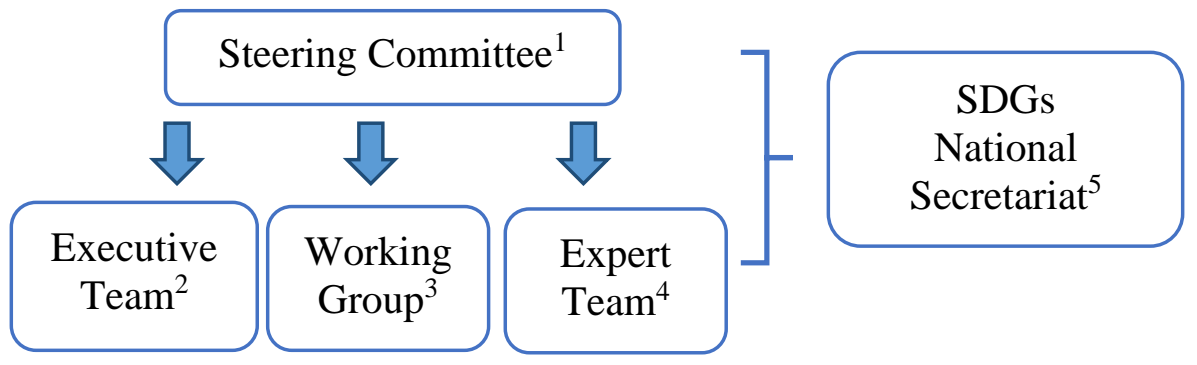

\section{Note:}

1. Steering Committee is consisted of:

a) President of Republic of Indonesia (Chairman)

b) Vice President of Republic of Indonesia (Vice Chairman)

c) Coordinating Minister for Economic Affairs (Vice Chairman 1)

d) Coordinating Minister for Human Development and Culture (Vice Chairman 2)

e) Coordinating Minister for the Ministry of Maritime Affairs (Vice Chairman 3)

f) Coordinating Minister for Political, Legal and Security Affairs (Vice Chairman 4)

g) Minister of National Development Planning/Head of Bappenas (Executive Coordinator)

h) Minister of Foreign Affairs (Member)

i) Minister of Home Affairs (Member)

j) Minister of Finance (Member)

k) Minister of State-Owned Enterprises (Member)

1) Cabinet Secretary (Member)

m) Chief of Staff of the Presidency (Member)

2. ExecutiveTeam is consisted of:

a) Deputy Minister of Marine Affairs and Natural Resources of the Ministry of National Development Planning (Chairman)

b) Representatives from Other Ministries/Institutions (Member)

c) Representatives from Philanthropy and Business Actors (Member)

d) Representatives from Academia Community (Member)

e) Representatives from Civil Society/Community Organizations (Member)

3. Working Group is consisted of various other institutions/professionals that are focusing their work on each Goals of SDGs' 17 Goals. These working groups are working alongside the Executive Team.

4. The Expert Team is consisted of various experts and/or professionals in each specific fields according to the each goals within the SDG's 17 Goals. The Expert Team will provide substantive advices and recommendations to the Executive Team accordingly.

5. The SDGs National Secretariat is providing an overall support to the National Coordination Team of SDGs in Indonesia (Steering Committee, Executive Team, Working Group and The Expert Team). 